補緅誌, J Jpn Prosthodont Soc, 30 : 929 940, 1986.

\title{
石こう系埋没材用寒天複印象材に関する研究
}

\author{
一反復使用が弾性ひずみ，色彩および複模型の精度に及ぼす影響について一
}

\section{石上 惠一}

\author{
A Study on the Duplicating Hydrocolloid Impression Materials \\ for Plaster-Bonded Investments \\ - Concerning the Effects of Their Repeated Use On the Strain in \\ Compression, Color and the Accuracy of Refactory Casts -
}

Keiichi Ishigami

\begin{abstract}
The duplicating hydrocolloid impression materials, because of their thermoplasticity, are used repeatedly without being discarded after each use.

So, the author this time conducted an experiment with the purpose of clarifying what kinds of effects are given, when a cast metal denture plate is made with nickel-chromium alloy, to the physical properties (the strain in compression and the color) of the duplicating hydrocolloid impression materials and to the accuracy of the refactory casts by the repetitive use of the impression materials which are used in impression-taking as the first step in the technical work, the process which is considered to vastly affect the fitness of the cast metal-denture plate to be made.
\end{abstract}

Key words : the duplicating hydrocolloid impression materials, used repeatedly, nickel-chromium alloy, physical properties, accuracy of the refactory casts

\section{第 1 章 緒 言}

複模型用寒天印象材は，鋳造床調製時の複印象材とし て，今日の補綴臨床には久かすことのできない材料の 1 つである1 5).

この種の印象材には, $\mathrm{Co}-\mathrm{Cr}$ 合金用と $\mathrm{Ni}-\mathrm{Cr}$ 合金用と の 2 種類があり ${ }^{6,7)}, \mathrm{Co}-\mathrm{Cr}$ 合金用にはリン酸塩系埋没材 が用いられ $1,3,4,8 \sim 16)$ ，それに応用される寒天複印象材に ついては，その基礎的検討などについて多くの報告 $1,3,8$, 16 20)がある.

しかし，Ni-Cr 合金用として使用される石こう系埋没

日本大学歯学部歯科補程学教室局部床義歯学講座

Department of Removable Partial Denture Prosthodontics, Nihon University School of Dentistry

昭和 61 年 4 月 16 日受付
材用の寒天複印象材についての報告 $3,6,21,22)$ は少ない.

この種の寒天印象材は, その使用にあたって熱可逆性 という性質から, 反復使用が可能であり ${ }^{1,3,6)}$, 日常の臨 床では, 経済性からも他の印象材と異なり, 使い衰てる ことなく反復使用している. この反復して使用すること が, 印象面の物理的性状を変化させ ${ }^{3)}$, 複模型の精度に も影響を及ぼし, それより得られる複模型の精度にも影 響をあたえ，ひいては鋳造床の適合性に影響4)すること が考えられる. Co-Cr 合金用として使用されるリン酸塩 系埋没材用寒天複印象材については, 当教室の伊保内 ${ }^{17)}$ が報告しているが， $\mathrm{Ni}-\mathrm{Cr}$ 合金用のそれについて，これ らを検討した報告は見当たらない。

そこで今回著者は, $\mathrm{Ni}-\mathrm{Cr}$ 合金で鋳造床を調製する際 に，その適合性に大きく影響すると思われる，技工操作 の第一歩である印象操作に使用される寒天複印象材の反 復使用が, その物理的性状（弾性ひずみおよび色彩）お 
表 1 材料

\begin{tabular}{|c|c|c|c|c|c|c|}
\hline 材 & 料 & 製造会社 & 商品名 & 製造番号 & 混水比 & 使用条件 \\
\hline \multirow{3}{*}{ 寒 } & \multirow{3}{*}{ 天 } & 松風 & デントダル & 048557 & & {$\left[\begin{array}{l}\text { 注入: } 50 \pm 2{ }^{\circ} \mathrm{C} \\
\text { 泠却: } 15 \text { 分放冷, } 40 \text { 分水冷 }\end{array}\right.$} \\
\hline & & 三金 & サニアガー & $151-158$ & & {$\left[\begin{array}{l}\text { 注入： } 50 \sim 55^{\circ} \mathrm{C} \\
\text { 冷却：15分放冷，30分水冷 }\end{array}\right.$} \\
\hline & & 而至 & ルークダル & 020851 & & {$\left[\begin{array}{l}\text { 注入: } 52 \pm 2{ }^{\circ} \mathrm{C} \\
\text { 汾却: } 10 \text { 分放冷, } 60 \text { 分水冷 }\end{array}\right.$} \\
\hline \multirow{3}{*}{\multicolumn{2}{|c|}{ 埋没材 }} & 松風 & デントハスト & 108451 & 0.26 & \\
\hline & & 三金 & サニメントD & 590627 & 0.26 & \\
\hline & & 而至 & ルークハスト & 240841 & 0.24 & \\
\hline
\end{tabular}

よび複模型の精度によ゙のような影響を及ぼすかを解明す る目的で, 伊保内 ${ }^{17)}$ の方法を参考に本実験に着手した.

すなわち，物理的性状としては，ADAS No. 20 に従い 弹性ひずみの測定 ${ }^{23)}$ および色彩の測定を行い24,25)，また 複模型の精度については, 三次元座標測定装置 ${ }^{26 ~ 28) ~}$ 用 いた三次元計測 ${ }^{29-31)}$ を行って, 寒天複印象材の反復使用 がそれらにおよぼす影響について検討した。

\section{第 2 章 材料および方法}

\section{1. 材料}

本実験に使用した石こう系埋没材用寒天複印象材（以 下，印象材と略す）および石こう系埋没材（以下，埋没 材と略す)は, 現在一般に使用頻度が高く，そして鋳造 システムの整った国産品の 3 社の製品を選択した.

すなわち，松風システム（㮫松風）のデントゲルとデ ントベスト，三金システム（三金工業揦）のサニアガー とサニメント D，拉よび G-C システム（而至菌科工業 琍）のルークゲルとルークベストであり，それらの使用 法を表 1 に示した。

\section{2. 方法}

1）弾性ひずみについて

弹性ひずみ測定用の試料は, ADAS No. 20 Type I Class 1 ${ }^{23)}$ に従い，試料作製用の金型 $(\phi 12.7 \times 19.0 \mathrm{~mm})$ 2 個を使用し，それぞれに溶解したジル状の印象材を注 入し, 同一時期に 2 個ずつ, 各印象材について繰返して 2 回の実験を行い, 各印象材の試料を合計 60 個 作製し た.

測定方法は, ADAS No. 20 の弾性ひずみ測定法 ${ }^{23)}$ に従 い測定した.

成績は，それぞれの反復使用回数時における 4 個の試
料の平均值と標準偏差とで示した. そして, 直線回帰式 $\mathrm{y}=\mathrm{ax}+\mathrm{b}^{34)}$ により，そ机を直線回帰分析して示した.

2) 色彩について

色彩測定用試料は, 溶解したジル状の印象材をそれぞ れガラスシャーレ $(\phi 90 \times 20 \mathrm{~mm})$ に注入して, 各印象 材について繰返し 2 回の実験を行い, 各印象材の試料を 合計 30 個作製した。

測定には, 明度は明度指数として $\mathrm{L}^{*} て ゙$, 色相と彩度 とは, これを同時に考えた場合の色の属性として, ク口 マチックネス指数 $\mathrm{a}^{*} \mathrm{~b}^{*}$ で表される CIE $1976\left(\mathrm{~L}^{*} \mathrm{a}^{*} \mathrm{~b}^{*}\right)$ 均等知覚空間 ${ }^{35)}$ を測定し, 表示することのできる ${ }^{24,25)}$ 色 彩色差計 CR 100 (ミノルタ)にて行った. 寸なわち, 溶 解されたゾル状の印象材を注入し, 30 分後に菅原 ${ }^{36)}$ の方 法に準じて, バックグランドの色彩を一定に保つため

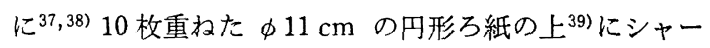
レを置いた，これは，印象材が半透明性であり，光の透 過拡散性の強い材料であるため, この性質を持つ材料の 色調が, 当然その背景の色に大きく影響されることが推 察されるためである ${ }^{38)}$.

測定は，1つの試料につき中心と思われる 1 カ所と， それより半径約 $10 \mathrm{~mm}$ と思われる同心円内の 2 力所と の計 3 力所で行った.

成績は, 6 力所測定における $\mathrm{L}^{*} \mathrm{a}^{*} \mathrm{~b}^{*}$ それぞれの平均 值と標準偏差とで示し, それを直線回帰分析を行い, そ して $\mathrm{L}^{*} \mathrm{a}^{*} \mathrm{~b}$ * 表色系色度図としても示した。

3）複模型について

(1) 原型

原型は，標準的な下頡の寸法 ${ }^{32,33)}$ を参考に，基礎的に その状態を把握することを目的として, アンダーカット の無い単純化した形態の歯列弓 ${ }^{32,33)}$ と，その歯列弓をネ ジで固定するために，また，石こう系耐火複模型（以 下，複模型と赂す）の計測基準を計測対象物の外に設定 
するために, 必要な計測原点を設定してある台座とから 構成された金属製である(図 1).

これらの材質は，歯列弓がオーステナイト采ステンレ ス (SUS 303) で, 台座が鋳鉄 (FC 20) である.

台座の寸法は, 図 2 に示寸ように, 縦 $165.40 \mathrm{~mm}$, 横 $165.50 \mathrm{~mm}$ の四角形であり，歯列弓は，幅 $8.75 \mathrm{~mm}$, 高 さ $10.50 \mathrm{~mm}$ ，テーパーを $1 / 10$ とした台座で作られてい る. また, 左右の側堤部の外側縁間距 離 は, $58.35 \mathrm{~mm}$, 内側縁間距離は $37.40 \mathrm{~mm}$ である。

(2) 印象用フラスコ

印象用フラスコ(以下, フラスコと略す) は, 伊保内 ${ }^{17}$ と各印象材の鋳造床システムのそれとを参考にして，厚 さが $14.20 \mathrm{~mm}$ の円筒形で，アルミニウム製である (図3).

各部の寸法は, 図 4 に示寸ように外径が $109.80 \mathrm{~mm}$, 高さが $74.40 \mathrm{~mm}$ であり, 印象材の注入孔の内径が

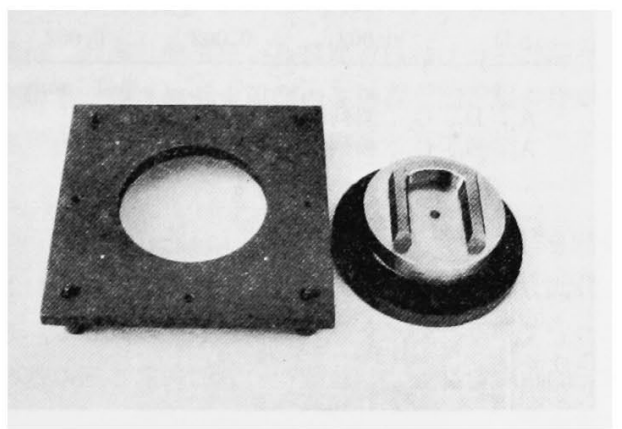

図1 原形

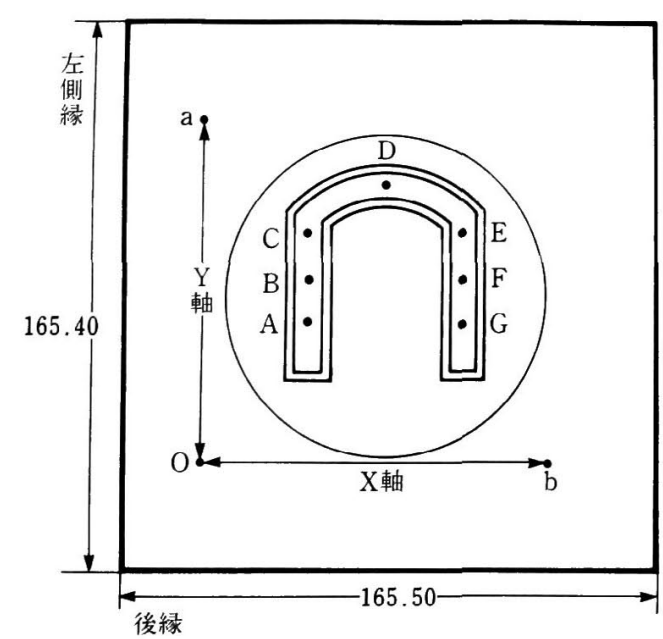

a 㐘列弓・台座および計測原点・基準点・測定点の上面図
$19.80 \mathrm{~mm}$ である.

（3）試料の作製扔よび測定

試料の作製は，まずどル状の印象材， $1.0 \mathrm{~kg}$ を計量し， これを寒天溶解保温器 (猁松風, 以下溶解器と略す) に 入れ, 約 1 時間かけて溶解し, その後表 1 に示寸メーカ 一指示の注入温度になるまで摫拌して,このジル状に溶 解した初回の試料を反復 1 回の試料とした.

反復使用による 2 回以降の試料は, 前回の試料作製に 用いたときのものと, 溶解器内に残った余剩のものとを 一緒にし，冷暗保存して，これを反復 1 回と同様に溶解 して試料作製に用いた，反復回数は，伊保内 ${ }^{17}$ の実験と 同様に 18 回までとした。

そして、これらについて弾性ひずみおよび色彩につい て, 同一実験を 2 回ずっ, 複模型の再現性については, 同一実験を 5 回行った.

測定は，伊保内 ${ }^{17)}$ の実験と同様に予備実験において各

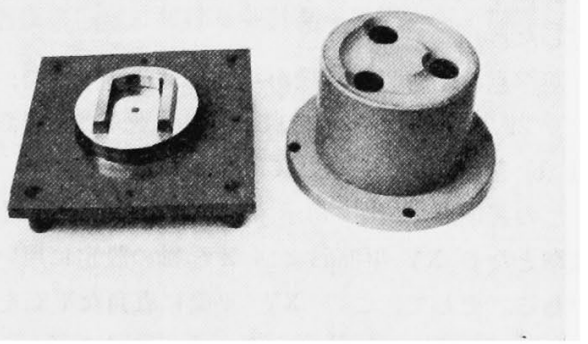

図 3 原形および印象用フラスコ

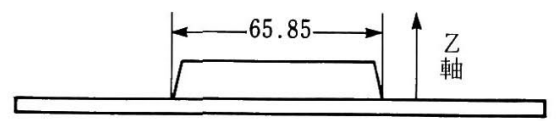

b 側面図

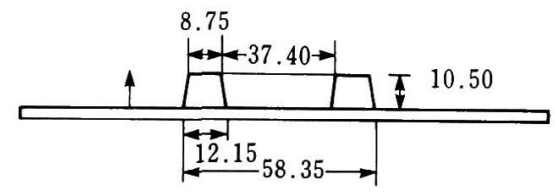

c 後面図

図 2 歯列弓および台座模型図 (単位 : $\mathrm{mm}$ ) 


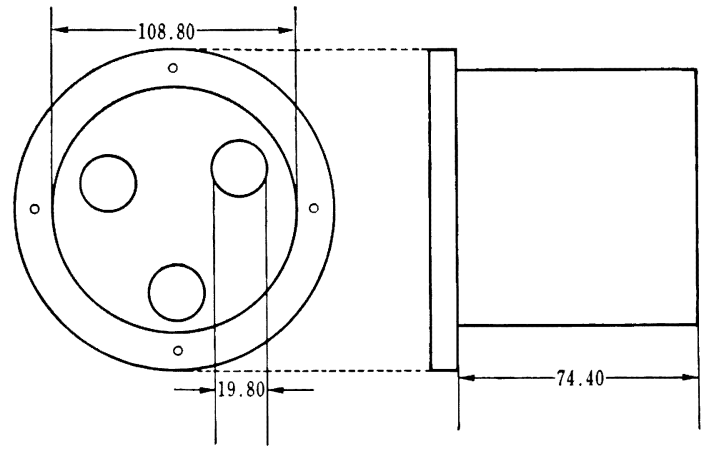

図 4 印象用フラスコ（単位：mm）

回に大きな差が認められない傾向がみられたので, 反復 1, 5, 10, 15 および 18 回目について, それぞれの試料を 測定した.

（4）計測原点, 基準点および計測点

図 2 に示すように, 計測原点 (0) は台座の後縁より $29.55 \mathrm{~mm}$ 前方で, 左側縁より $34.85 \mathrm{~mm}$ 右方の交点の 位置に $\phi 1.0 \mathrm{~mm}$ のラウンドバーでポンチングをして設 定した.

基準点は, 台座の前縁から $30.20 \mathrm{~mm}$ 後方で, 左側縁 より $29.10 \mathrm{~mm}$ 右方の交点 (a) と計測原点とで直交する 点 (b) をポンチングをして設定した.

この基準点は, 図 2 に示すとおり複模型を計測する際, 基準となる $\mathrm{XY}$ 平面および $\mathrm{XY}$ 軸の設定に用いるもの である.そして，この $\mathrm{XY}$ 平面に直角な平面を $\mathrm{Z}$ 平面 とし，計測原点 (0) をとおる軸を $\mathrm{Z}$ 軸とし設定した.

また，歯列弓の計測点においても，図 2 に示すとおり であり，左側大白歯相当部を $\mathrm{A}$ ，左右側小臼歯相当部を $\mathrm{B}$ ，左側犬歯相当部を C, 中切歯相当部を $\mathrm{D}$, 右側犬歯相 当部を $\mathrm{E}$ ，右側小臼歯相当部を $\mathrm{F}$ ，そして右側大臼歯相 当部を $\mathrm{G}$ とし, $A \sim G$ の計 7 点を $\phi 1.0 \mathrm{~mm}$ のラウンド バーにてポンチングをして計測点として設定した. これ ら 7 点の計測点について, 計測原点 (0) よりその三次 元的距離と $\mathrm{XY}, \mathrm{XZ}$ および $\mathrm{YZ}$ の各平面における距離 とを表 2 に示した.

（5）歯列弓の位置再現精度について

今回の実験において, 歯列弓の金型（以後，金型と略 す）より複模型を作製するには，まず台座に金型をネジ 止めし，フラスコを上面より被せ，そこに印象材を注入 し複印象をする. つぎに, 印象材硬化後台座の裏面より ネジ止めされた金型を一度取りはずすことになるので, 印象材を反復使用した．複模型を数個作製するには，着 脱による金型の位置の再現精度が問題となるため，その
表 2 歯列弓各計測点の距離

\begin{tabular}{|c|c|c|c|c|}
\hline 計測点 & 三次元的距離 & \multicolumn{3}{|c|}{ 各 軸 距 離 } \\
\hline & & $\mathrm{X}$ 軸 & $Y$ 軸 & Z 軸 \\
\hline A & 54.155 & 24.150 & 42.228 & 23.797 \\
\hline B & 66.474 & 24.191 & 57.163 & 23.789 \\
\hline $\mathrm{C}$ & 83.044 & 24.345 & 75.734 & 23.833 \\
\hline $\mathrm{D}$ & 101.510 & 47.483 & 86.457 & 23.975 \\
\hline $\mathrm{E}$ & 106.564 & 69.122 & 77.518 & 23.855 \\
\hline $\mathrm{F}$ & 94.673 & 70.281 & 58.753 & 23.910 \\
\hline G & 86.727 & 70.769 & 44.100 & 23.845 \\
\hline
\end{tabular}

表 3 歯列弓の位置再現精度

\begin{tabular}{cccc}
\hline \hline & $\mathrm{A}_{2}-\mathrm{A}_{1}$ & $\mathrm{D}_{2}-\mathrm{D}_{1}$ & $\mathrm{G}_{2}-\mathrm{G}_{1}$ \\
\hline 1 & 0.010 & 0.008 & 0.008 \\
2 & 0.010 & 0.011 & 0.012 \\
3 & 0.011 & 0.009 & 0.010 \\
4 & 0.005 & 0.007 & 0.006 \\
5 & 0.008 & 0.006 & 0.009 \\
Mean & 0.009 & 0.006 & 0.009 \\
S.D. & 0.002 & 0.002 & 0.002 \\
\hline
\end{tabular}

$A_{1}, D_{1}, G_{1}$ : 歯列弓取りはずし前

$A_{2}, D_{2}, G_{2}$ : 歯列弓再装着後

計測を行った.

計測方法については, 金型上の計測点 $\mathrm{A}, \mathrm{D}$ および $\mathrm{G}$ についてのみ行い, 金型の着脱を 5 回繰返して, その三 次元的距離を計測し, 星野 ${ }^{30)}$ の方法に準じその差の精度 を求めた。

その結果を表 3 に示すとおり，各計測点における平均 值は, ともに $10 \mu \mathrm{m}$ 以下であった.

（6）試料の作製

試料作製は，まず原型とフラスコとをネジ止めして固 定し, ゾル化した印象材をフラスコの注入孔より注入し た後, この印象を室温放冷し, さらに水没して水冷を行 った.

印象材がゲル化したのち, 原型の裏面より台座底部の 4 つの金型固定ネジ $(\phi 5 \times 27.0 \mathrm{~mm})$ を取りはずして, 金型を取り除き，そのネジ穴に複模型を固定するための 固定用ネジを差し込み，バイブレーター上にフラスコの 上縁が下方になるよう載せた（図 5).

つぎに，各印象材とシステム化されたそれぞれの埋没 材を $250 \mathrm{~g}$ ずつ計量してラバーボールに取り, 表 1 に示 すメーカー指示の混水比にて, 真空練和器 (トーワ技研, コーネル）を用いて練和を行った. そして，練和された 埋没材を, 台座裹面の埋没材注入孔より印象材陰型内に 
注入し, 60 分後に台座よりフラスコおよび印象材を取り 除き, 台座に固定された複模型をさらに 60 分後に計測 に供した

このようにして，各印象材について繰返し 5 回の実験 を行い, 25 個ずつ計 75 個の複模型を作製した.

（7）複模型の計測

複模型の計測は，複模型作製 120 分後に行った.

まず，三次元座標測定装置 XYZAX M 400-300 D 26 28) (東京精密) に接触式 $\phi 1 \mathrm{~mm}$ のスイングローブを取り 付け，この装置のワークテーブル上に台座に固定された 複模型をのせ，その台座を位置付けして固定し，ミニコ ンピューターNOVA 4 C 型（日本データゼネラル社）を 連動させて行った.

計測は，台座上にポンチングされた計測原点から金型 の各計測点 $A \sim G$ までに相当する複模型上の各計測点 $\mathrm{A}^{\prime} \sim \mathrm{G}^{\prime}$ のそれぞれの三次元的距離を三次元的変位率と して，また $\mathrm{X}, \mathrm{Y}$ および $\mathrm{Z}$ 軸の各軸における距離を各軸 変位率として求めた。

成績は，台座計測原点から複模型における各計測点ま での距離と, 表 2 に示す原型の各計測点間距離の差から 変位率31)を求め, それぞれの平均値と標準偏差とで示し

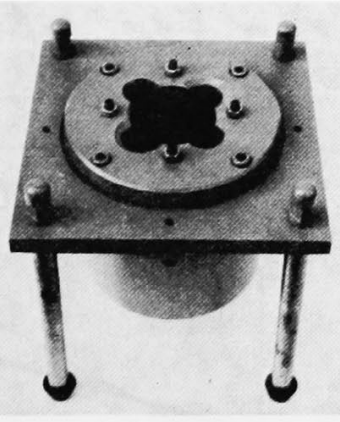

図 5 台座底部
た.

なお，各試料作製と測定および計測は，室温 $23 \pm 2{ }^{\circ} \mathrm{C}$, 相対湿度 $50 \pm 10 \%$ の環境下で行った。

\section{第 3 章 成 績}

\section{1. 印象材の弾性ひずみ}

弾性ひずみの成績を表 4 に，3 種類の印象材の各反復 回数における平均値と標準偏差とで示した.

\section{2. 印象材の色彩}

色彩の成績を表 5 および図 6 に，3 種類の印象材の反 復回数における $L^{*} a^{*}$ および b* のそれぞれを平均値と 標準偏差で示し，また，L*a*b* 表色系色度図を図 8 に 示した

\section{3. 複模型の変位率}

1) 三次元的変位率

複模型の三次元的変位率の成績を表 6 に, 3 種類の複 模型の各反復回数における各計測点の平均值と標準偏差

表 4 印象材の弾性ひずみ

\begin{tabular}{|c|c|c|c|c|}
\hline \multicolumn{2}{|c|}{ 反復回数 } & デントゲル & サニアガー & ルークゲル \\
\hline \multirow[t]{2}{*}{1 回 } & Mean & 19.5 & 14.1 & 12.2 \\
\hline & SD & 0.4 & 0.2 & 0.2 \\
\hline \multirow[t]{2}{*}{5 回 } & Mean & 18.1 & 13.2 & 11.3 \\
\hline & $\mathrm{SD}$ & 0.2 & 0.3 & 0.4 \\
\hline \multirow[t]{2}{*}{10 回 } & Mean & 17.1 & 12.2 & 10.1 \\
\hline & $\mathrm{SD}$ & 0.4 & 0.4 & 0.2 \\
\hline \multirow[t]{2}{*}{15 回 } & Mean & 16.0 & 11.1 & 9.3 \\
\hline & $\mathrm{SD}$ & 0.3 & 0.3 & 0.3 \\
\hline \multirow[t]{2}{*}{18 回 } & Mean & 14.7 & 9.9 & 8.8 \\
\hline & $\mathrm{SD}$ & 0.5 & 0.4 & 0.3 \\
\hline
\end{tabular}

表 5 印象材の色彩

\begin{tabular}{|c|c|c|c|c|c|c|c|c|c|c|}
\hline \multicolumn{2}{|c|}{ 反復回数 } & \multicolumn{3}{|c|}{ デントゲル } & \multicolumn{3}{|c|}{ サニアガー } & \multicolumn{3}{|c|}{ ルークダル } \\
\hline & & $L^{*}$ & $a^{*}$ & $b^{*}$ & $\mathrm{~L}^{*}$ & $a^{*}$ & $\mathrm{~b}^{*}$ & $\mathrm{~L}^{*}$ & $a^{*}$ & $\mathrm{~b}^{*}$ \\
\hline \multirow[t]{2}{*}{1 回 } & Mean & 34.3 & 1.1 & -8.8 & 42.2 & 1.2 & -7.5 & 39.1 & 0.8 & -6.6 \\
\hline & $\mathrm{SD}$ & 0.3 & 0.1 & 0.1 & 0.3 & 0.2 & 0.3 & 0.2 & 0.1 & 0.2 \\
\hline \multirow[t]{2}{*}{5 回 } & Mean & 32.2 & 0.8 & -7.8 & 40.0 & 0.8 & -6.2 & 38.4 & 0.7 & -5.9 \\
\hline & SD & 0.2 & 0.1 & 0.1 & 0.8 & 0.1 & 0.3 & 0.1 & 0.1 & 0.1 \\
\hline \multirow[t]{2}{*}{10 回 } & Mean & 31.3 & 0.7 & -6.5 & 38.6 & 0.7 & -5.1 & 37.9 & 0.5 & -5.3 \\
\hline & $\mathrm{SD}$ & 0.2 & 0.1 & 0.1 & 0.3 & 0.1 & 0.2 & 0.2 & 0.1 & 0.2 \\
\hline \multirow[t]{2}{*}{15 回 } & Mean & 30.6 & 0.7 & -4.2 & 36.9 & 0.6 & -4.3 & 37.2 & 0.4 & -4.4 \\
\hline & $\mathrm{SD}$ & 0.1 & 0.1 & 0.2 & 0.1 & 0.1 & 0.4 & 0.4 & 0.1 & 0.2 \\
\hline \multirow[t]{2}{*}{18 回 } & Mean & 29.2 & 0.2 & -2.3 & 35.8 & 0.3 & -3.9 & 35.8 & 0.3 & -3.4 \\
\hline & $\mathrm{SD}$ & 0.2 & 0.1 & 0.2 & 0.3 & 0.1 & 0.2 & 0.2 & 0.1 & 0.1 \\
\hline
\end{tabular}


表 6 複模型の三次元的変位率

\begin{tabular}{|c|c|c|c|c|c|c|c|c|c|}
\hline & 反復回数 & & $A^{\prime}$ & $B^{\prime}$ & $C^{\prime}$ & $\mathrm{D}^{\prime}$ & $E^{\prime}$ & $F^{\prime}$ & $\mathrm{G}^{\prime}$ \\
\hline \multirow{5}{*}{ 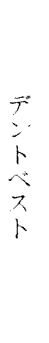 } & 1 回 & $\begin{array}{c}\text { Mean } \\
\mathrm{SD}\end{array}$ & $\begin{array}{l}0.63 \\
0.05\end{array}$ & $\begin{array}{l}0.41 \\
0.07\end{array}$ & $\begin{array}{l}0.36 \\
0.02\end{array}$ & $\begin{array}{l}0.22 \\
0.04\end{array}$ & $\begin{array}{l}0.29 \\
0.01\end{array}$ & $\begin{array}{l}0.56 \\
0.06\end{array}$ & $\begin{array}{l}0.58 \\
0.05\end{array}$ \\
\hline & 5 回 & $\begin{array}{l}\text { Mean } \\
\text { SD }\end{array}$ & $\begin{array}{l}0.72 \\
0.02\end{array}$ & $\begin{array}{l}0.48 \\
0.03\end{array}$ & $\begin{array}{l}0.40 \\
0.05\end{array}$ & $\begin{array}{l}0.30 \\
0.04\end{array}$ & $\begin{array}{l}0.38 \\
0.03\end{array}$ & $\begin{array}{l}0.64 \\
0.07\end{array}$ & $\begin{array}{l}0.76 \\
0.06\end{array}$ \\
\hline & 10 回 & $\begin{array}{c}\text { Mean } \\
\text { SD }\end{array}$ & $\begin{array}{l}0.51 \\
0.12\end{array}$ & $\begin{array}{l}0.34 \\
0.03\end{array}$ & $\begin{array}{l}0.25 \\
0.03\end{array}$ & $\begin{array}{l}0.16 \\
0.02\end{array}$ & $\begin{array}{l}0.20 \\
0.02\end{array}$ & $\begin{array}{l}0.34 \\
0.05\end{array}$ & $\begin{array}{l}0.43 \\
0.09\end{array}$ \\
\hline & 15 回 & $\begin{array}{l}\text { Mean } \\
\text { SD }\end{array}$ & $\begin{array}{l}0.35 \\
0.12\end{array}$ & $\begin{array}{l}0.27 \\
0.02\end{array}$ & $\begin{array}{l}0.21 \\
0.03\end{array}$ & $\begin{array}{l}0.11 \\
0.03\end{array}$ & $\begin{array}{l}0.14 \\
0.02\end{array}$ & $\begin{array}{l}0.20 \\
0.04\end{array}$ & $\begin{array}{l}0.30 \\
0.07\end{array}$ \\
\hline & 18 [0] & $\begin{array}{c}\text { Mean } \\
\text { SD }\end{array}$ & $\begin{array}{l}0.25 \\
0.23\end{array}$ & $\begin{array}{l}0.18 \\
0.03\end{array}$ & $\begin{array}{l}0.14 \\
0.01\end{array}$ & $\begin{array}{l}0.05 \\
0.03\end{array}$ & $\begin{array}{l}0.144 \\
0.03\end{array}$ & $\begin{array}{l}0.03 \\
0.09\end{array}$ & $\begin{array}{l}0.10 \\
0.06\end{array}$ \\
\hline \multirow{5}{*}{$\begin{array}{l}\frac{+}{二} \\
x \\
\vdots \\
1 \\
D\end{array}$} & 1 回 & $\begin{array}{c}\text { Mean } \\
\text { SD }\end{array}$ & $\begin{array}{l}0.79 \\
0.02\end{array}$ & $\begin{array}{l}0.52 \\
0.08\end{array}$ & $\begin{array}{l}0.34 \\
0.20\end{array}$ & $\begin{array}{l}0.29 \\
0.05\end{array}$ & $\begin{array}{l}0.40 \\
0.04\end{array}$ & $\begin{array}{l}0.53 \\
0.05\end{array}$ & $\begin{array}{l}0.71 \\
0.05\end{array}$ \\
\hline & 5 回 & $\begin{array}{c}\text { Mean } \\
\text { SD }\end{array}$ & $\begin{array}{l}0.87 \\
0.10\end{array}$ & $\begin{array}{l}0.52 \\
0.08\end{array}$ & $\begin{array}{l}0.34 \\
0.20\end{array}$ & $\begin{array}{l}0.29 \\
0.05\end{array}$ & $\begin{array}{l}0.40 \\
0.04\end{array}$ & $\begin{array}{l}0.53 \\
0.05\end{array}$ & $\begin{array}{l}0.71 \\
0.05\end{array}$ \\
\hline & 10 回 & $\begin{array}{l}\text { Mean } \\
\text { SD }\end{array}$ & $\begin{array}{l}0.70 \\
0.09\end{array}$ & $\begin{array}{l}0.44 \\
0.04\end{array}$ & $\begin{array}{l}0.31 \\
0.06\end{array}$ & $\begin{array}{l}0.19 \\
0.11\end{array}$ & $\begin{array}{l}0.32 \\
0.03\end{array}$ & $\begin{array}{l}0.35 \\
0.03\end{array}$ & $\begin{array}{l}0.57 \\
0.04\end{array}$ \\
\hline & $15[0]$ & $\begin{array}{l}\text { Mean } \\
\text { SD }\end{array}$ & $\begin{array}{l}0.60 \\
0.07\end{array}$ & $\begin{array}{l}0.38 \\
0.04\end{array}$ & $\begin{array}{l}0.23 \\
0.05\end{array}$ & $\begin{array}{l}0.15 \\
0.04\end{array}$ & $\begin{array}{l}0.20 \\
0.04\end{array}$ & $\begin{array}{l}0.23 \\
0.05\end{array}$ & $\begin{array}{l}0.31 \\
0.10\end{array}$ \\
\hline & 18 回 & $\begin{array}{c}\text { Mean } \\
\text { SD }\end{array}$ & $\begin{array}{l}0.35 \\
0.08\end{array}$ & $\begin{array}{l}0.19 \\
0.06\end{array}$ & $\begin{array}{l}0.10 \\
0.04\end{array}$ & $\begin{array}{l}0.12 \\
0.14\end{array}$ & $\begin{array}{l}0.08 \\
0.04\end{array}$ & $\begin{array}{l}0.03 \\
0.07\end{array}$ & $\begin{array}{l}0.09 \\
0.09\end{array}$ \\
\hline \multirow{5}{*}{\begin{tabular}{l}
$ル$ \\
1 \\
$y$ \\
\hdashline \\
$x$ \\
5
\end{tabular}} & 1 回 & $\begin{array}{c}\text { Mean } \\
\text { SD }\end{array}$ & $\begin{array}{l}0.44 \\
0.05\end{array}$ & $\begin{array}{l}0.30 \\
0.06\end{array}$ & $\begin{array}{l}0.28 \\
0.05\end{array}$ & $\begin{array}{l}0.19 \\
0.02\end{array}$ & $\begin{array}{l}0.26 \\
0.03\end{array}$ & $\begin{array}{l}0.44 \\
0.01\end{array}$ & $\begin{array}{l}0.52 \\
0.08\end{array}$ \\
\hline & 5 回 & $\begin{array}{l}\text { Mean } \\
\text { SD }\end{array}$ & $\begin{array}{l}0.50 \\
0.08\end{array}$ & $\begin{array}{l}0.33 \\
0.14\end{array}$ & $\begin{array}{l}0.31 \\
0.04\end{array}$ & $\begin{array}{l}0.25 \\
0.03\end{array}$ & $\begin{array}{l}0.35 \\
0.03\end{array}$ & $\begin{array}{l}0.90 \\
0.06\end{array}$ & $\begin{array}{l}0.69 \\
0.06\end{array}$ \\
\hline & 10 回 & $\begin{array}{l}\text { Mean } \\
\text { SD }\end{array}$ & $\begin{array}{l}0.41 \\
0.09\end{array}$ & $\begin{array}{l}0.28 \\
0.03\end{array}$ & $\begin{array}{l}0.24 \\
0.05\end{array}$ & $\begin{array}{l}0.13 \\
0.03\end{array}$ & $\begin{array}{l}0.17 \\
0.05\end{array}$ & $\begin{array}{l}0.28 \\
0.07\end{array}$ & $\begin{array}{l}0.32 \\
0.09\end{array}$ \\
\hline & 15 回 & $\begin{array}{c}\text { Mean } \\
\text { SD }\end{array}$ & $\begin{array}{l}0.34 \\
0.02\end{array}$ & $\begin{array}{l}0.23 \\
0.03\end{array}$ & $\begin{array}{l}0.16 \\
0.04\end{array}$ & $\begin{array}{l}0.07 \\
0.03\end{array}$ & $\begin{array}{l}0.08 \\
0.03\end{array}$ & $\begin{array}{l}0.09 \\
0.05\end{array}$ & $\begin{array}{l}0.19 \\
0.08\end{array}$ \\
\hline & 18 回 & $\begin{array}{c}\text { Mean } \\
\text { SD }\end{array}$ & $\begin{array}{l}0.25 \\
0.03\end{array}$ & $\begin{array}{l}0.16 \\
0.06\end{array}$ & $\begin{array}{l}0.08 \\
0.03\end{array}$ & $\begin{array}{l}0.01 \\
0.03\end{array}$ & $\begin{array}{r}-0.01 \\
0.04\end{array}$ & $\begin{array}{r}-0.07 \\
0.09\end{array}$ & $\begin{array}{l}0.02 \\
0.08\end{array}$ \\
\hline
\end{tabular}
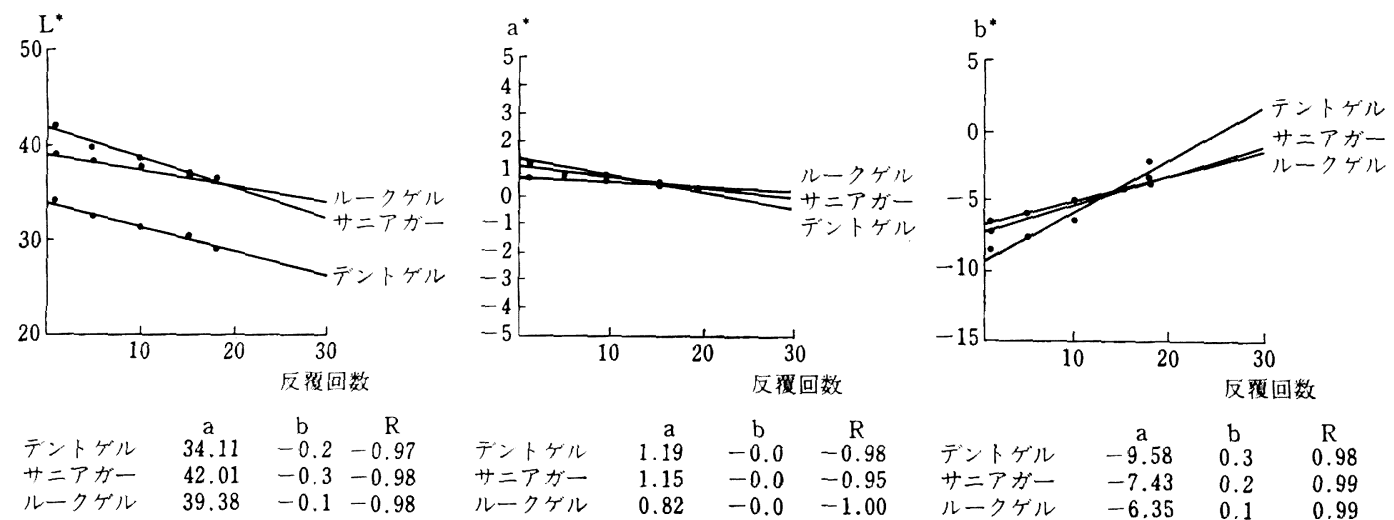

図 6 印象材の色彩

とで示した,

2) 各軸変位率

複模型の各軸変位率の成績を表 7 に, 各計測点におけ る $\mathrm{X}, \mathrm{Y}$ および Z軸のそれぞれを平均値と標準偏差とで
示した.

なお，成績中の正とは，原型において計測原点より金 型の計測点までの距離よりも, 台座の計測原点から複模 型の計測点までの距㒕の方が長い場合であり，負はその 


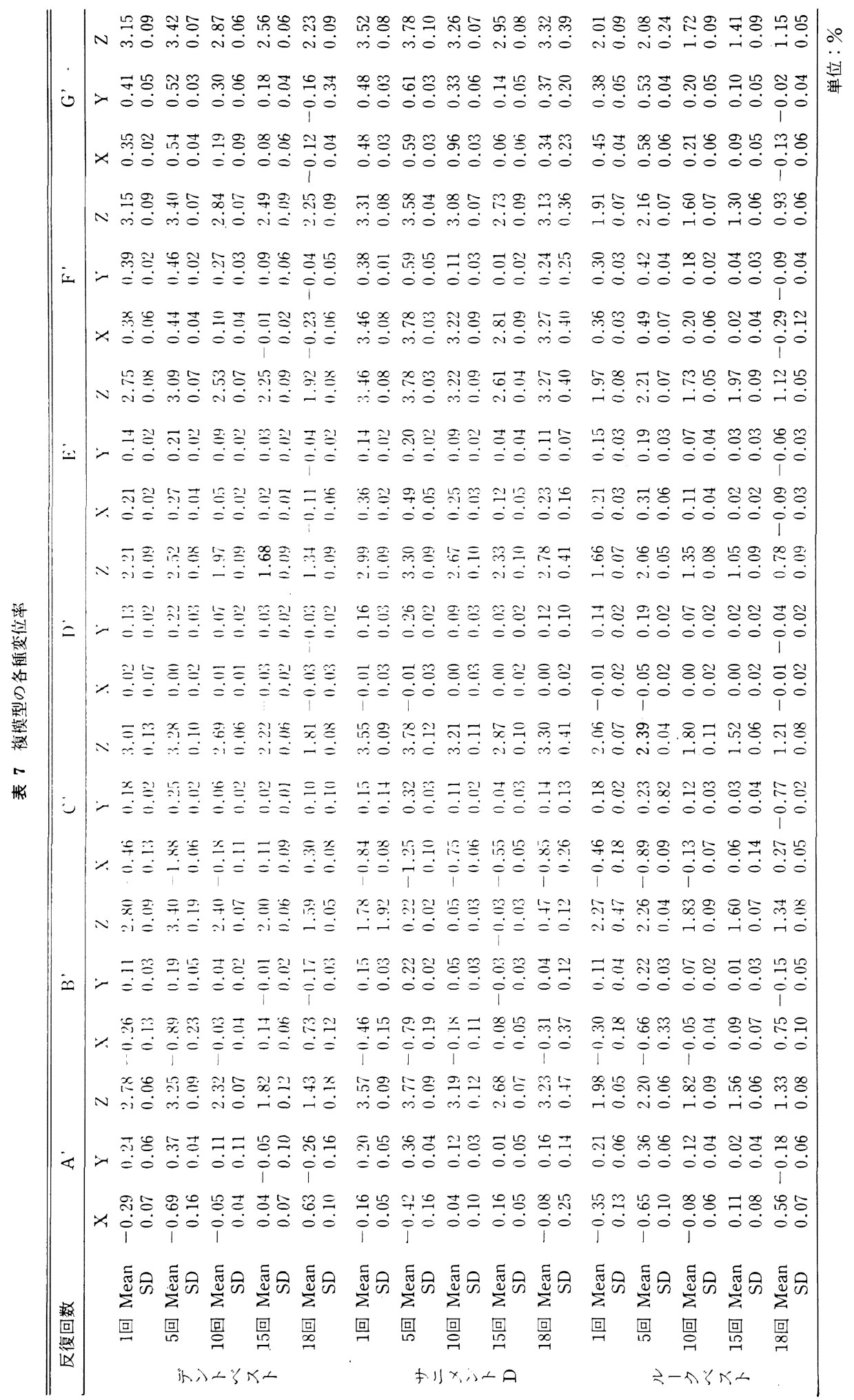


反対の場合である.

\section{第 4 章＼cjkstart総括および検討}

日常の補緅臨床における鋳造床の調製は, $\mathrm{Co}-\mathrm{Cr}$ 合金 による義歯がその主流をなしている ${ }^{7,40)}$. また, Satoh ら ${ }^{40)}$ の技工所の調査によっても，現在の鋳造床は $\mathrm{Ni}-\mathrm{Cr}$ 合金を取り扱う技工所よりも， Co- Cr 合金を取り扱う技 工所の方が多いとされている.

しかし，局部床義歯は 1 歯欠損から 1 歯残存まで ${ }^{111}$ ， また同一久損でも残存歯の状況および久損題堤の状況に より，その設計が複雑，多岐にわたることが多く，その 場合には，その適合性が問題となる。この鋳造床の適合 性を考虑した場合には，Co-Cr 合金より焼着反応が緩や かで，鋳造体表面の滑沢なものが得られる $\mathrm{Ni}-\mathrm{Cr}$ 合金 の応用 ${ }^{6)}$ が考えられ，石こう采埋没材が使用される.

また，この埋没材を使用して鋳造床用の複模型を作製 する場合には，その専用の印象材が用いられる。この印 象材には, 流動性や再現性がよく, 寸法安定性にも優 れ, 亡た弾性回復が速やかで, 親模型の表面となじみも 良く，無害，無刺激性で，カビないことなど，多くの所 要性質1,3,23) 備えているものが要求され，これには熱可 逆性 ${ }^{1,3,23)}$ の寒天複印象材が用いられている.

以上のように同一鋳造床を調製する場合でも，症例に よってその使用合金を変える場合があり， Co- $\mathrm{Cr}$ 合金応 用時に使用される印象材掞よび埋没材についての報告 は当教室の伊保内 ${ }^{17)}$ が報告しているが，石こう系につい ての報告はいまだ不十分である.

そこで著者は, 局部床義歯学における臨床の立場から 伊保内 ${ }^{17)}$ が行った $\mathrm{Co}-\mathrm{Cr}$ 合金応用時のリン酸塩系用寒 天複印象材の研究に引き続いて, 石こう系用寒天複印象 材についても，その物理的性状抢よび複模型の精度につ いて検討する必要があると喼め, 本実験を行った。

\section{1. 印象材の弾性ひずみについて}

局部床義歯調製時の印象は，その対象が硬組織の残存 歯と軟組織の䫈粘膜であり，それぞれ大なり小なり添窝 域を有している.このそれぞれの添窝域を適正に再現す るに注, 適度の弾性を有した印象材が応用される。また， この印象面より得られた親模型を複製して複模型を作製 する場合も，同様に弾性のある印象材が要求され，それ には弾性印象材の 1 つである寒天複印象材が応用されて いる.

この寒天複印象材は熱可逆性1,3,23)で，経済性からも，

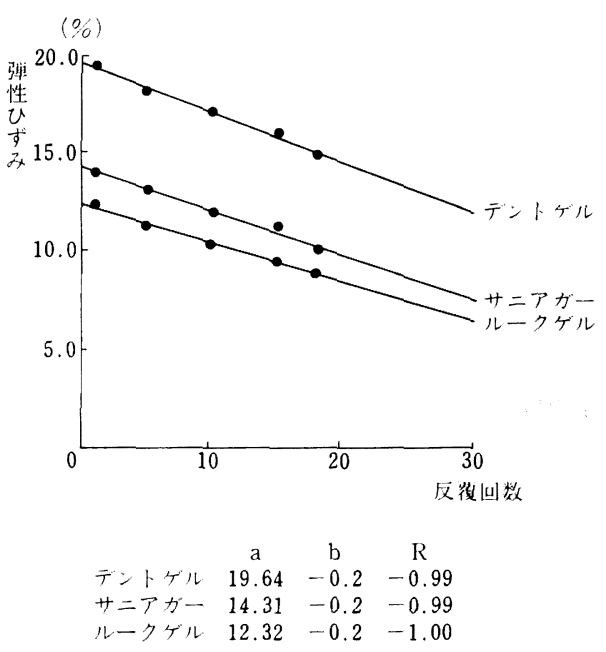

図 7 弾性ひずみの直線回帰

それを反復使用している3ののが一般的である。この反復 して使用することが弾性ひずみにどのように影響するか を検討するために，本実験を行った。

本実験の成績（表 4）より，印象材を反復して使用す ることが弾性ひずみにどのように影響するかを，直線回 帰分析して検討した。そ結果を図 7 に示し，その下段 に值線回帰式 $\mathrm{y}=\mathrm{ax}+\mathrm{b}$ における $\mathrm{a} ， \mathrm{~b}$ および相関係数 $\mathrm{R}$ を示した. 本成績より， 3 種類の印象材とも伊保内 ${ }^{17)}$ のそれと同様, ADAS No. 20 で示されている定荷重法に よる弾性ひずみ $4.0 〜 25.0 \%{ }^{23)}$ の範囲内であった.

川原ら ${ }^{3)}$ の報告によると，寒天印象材を反復して使用 するとその回数が増えるに従って急激に弾性ひずみが低 下するとしているが，本実験（図 7) では，伊保内 ${ }^{17)}$ と 同様に，反復回数が多くなるにつれ漸次直線的にその弾 性ひずみが低下しており，川原らゔのう急激な弾性ひ ずみの低下傾向は認められなかった。

これは，この印象材が熱可逆性材料の水成コロイド印 象材 ${ }^{21)}$ であるため水分が多く ${ }^{3,4)}$ ，それを反復して使用す ることにより, 加熱操作中に寒天中の水分が蒸発してし まい，また材料の組成も当初のそれとは変わることにも なる ${ }^{21)}$.

この点から考えると, 川原ら ${ }^{3)}$ は寒天印象材の溶解に 開放なべを使用しており, 著者は自動寒天溶解保存装置 を使用しているため, その溶解法の相違によるものと思 われる。

したがって，著者の溶解法と同様かもしくは類似した 方法であれば，寒天材料の性質すなわち，多糖類である という性質から徐々に多糖類が加水分解され，その強さ 
と弾性が隇少する゙)ことにより，弾性ひずみの急激な低 下はみられず，漸次低下してくるものと思われる.

以上のように寒天の溶解性の相違によってその弾性ひ ずみの減少傾向に遅速はあるが，反復使用によって弾性 ひずみは漸次減少することから, これに関する印象材の 反復使用の臨床的な限界基準の判断として，その弾性を 経験的に手指により決定している40)ことは意味があり， 有効な手段であると思われる.

\section{2. 印象材の色彩について}

Satoh ら ${ }^{40)}$ のアンケート調查および日常の臨床技工操 作からみると, この寒天印象材の反復使用におけるその 臨床的な限界判断基準の 1 つとして触覚と視覚とに依っ ている.したがって, 本実験ではこの視覚による判定の 一助として色彩の影響42)を検討した.

この測定に当っては, 近年そのものがそのまま人間の 知覚に対応しその色の差を数値として測定することが可 能になった, 三刺激值直読方式色彩色差計を使用して,

印象材の反復使用による色彩の変化を測定した.

各印象材に関する $\mathrm{L}^{*} \mathrm{a} * \mathrm{~b} *$ の平均值および標準偏差の 成績を表 5 に示した.

また, 印象材の反復使用による色彩の影響42)を検討す るため,この表から直線回帰分析を行い, その結果を図 6 に, 下段に直線回帰式 $\mathrm{y}=\mathrm{ax}+\mathrm{b}$ における $\mathrm{a}, \mathrm{b}$ およ び相関係数 Rを示した.

この図から明らかなように， 3 種類の印象材とも $\mathrm{L}^{*}$ および $\mathrm{a}^{*}$ はともに負の相関を示したのに対し, b* は逆 に正の相関を示した.

また, 各印象材の反復使用による色彩の影響42)をみる と, $\mathrm{L}^{*} \mathrm{a}^{*}$ および $\mathrm{b}^{*}$ ともに特定の反復使用回数による急 激な色彩変化は認められず, 漸次直線的に変化する傾向 が認められた．以上の表 5 および図 6 からは，色を視覚 として識別しにくいので， L*a*b* 表色系色度図を図 8 として作成した.

この図上り， L* (明度) は， 3 種類の印象材ともに反 復回数が多くなるにつれて低下する傾向が認められた. また, $\mathrm{a}$ * $\mathrm{b} *$ は原点を無彩色とした色相と彩度に対応して おり，反復使用による影響は，回数が増加するに従って， 3 種類の印象材は原点に向かって彩度が減少し, 退色 ${ }^{35)}$ する傾向を示している.

これは, 反復使用の度に溶解による寒天印象材中の水 分が蒸発することによる濃縮およびそのための組成変 化光と，印象材一の埋没材の付着およびカビ $1,3,23)$ などが， 寒天複印象材の彩度に影響したものと考えられる。
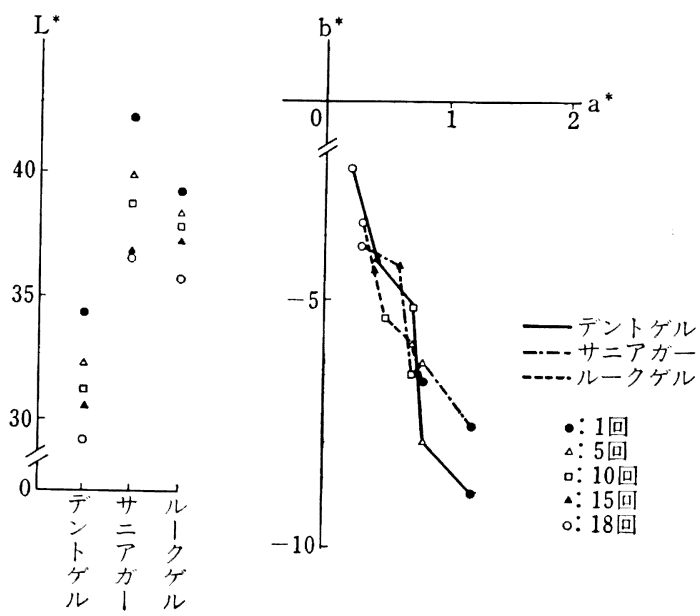

図 8 印象材の $\mathrm{L}^{*} \mathrm{a}^{*} \mathrm{~b}^{*}$ 表色采色度図

したがって, 本実験の結果から, 印象材は反復して使 用することにより色彩が漸次変化するので，その使用に 当って色彩を臨床的な限界基準の一助として判断するこ とは意味あることであり，有効な手段と思われる。

\section{3. 複模型の変位率}

1) 三次元的変位率

近年, 臨床的な模型計測の傾向は, その精度を適切に 評価するために, 三次元的に精密に検索したものが多 ( $8,26 \sim 31)$.

したがって, 本実験の模型計測においても, 伊保内 ${ }^{17)}$ に準じ, 三次元測定装置を使用して, 複模型の変位変形 を測定した. その結果を表 6 に示した。

その結果をみると、デントベストは， $A^{\prime} 〜 G^{\prime}$ の各計 測点において, 反復 5 回の複模型が一番高い変位率を示 して抢り，ついで 1，10，15，18 回の順に少なくなる傾向 を示している.これは，\#ニメントDおよびルークベス トによる複模型においても同様な傾向を示した.

これは, 伊保内 ${ }^{17)}$ と同様な結果であり, 同様のことが 考えられる. すなわち, 印象材の反復回数が多くなるに つれ, 印象材中の液体成分 (95\%) が溶解操作の綝返し により蒸発したり，模型材に吸収され，その量が渐次減 少し, それによる水和膨張量の減少が, 複模型に変形,

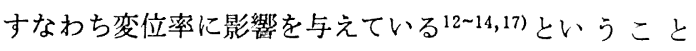
が考えられる.

したがって, 反復回数が多くなると, $\mathrm{Ni}-\mathrm{Cr}$ 合金の鋳 造収縮率に影響を与えることが考えられ，その使用に当 っては熱可逆性で反復使用が可能な材料といえども, 反 復して使用する回数はあまり多くないほうが良いと思わ 
れる。

\section{2）各軸変位率}

各軸における複模型の変位率の成績を表 7 に示す。こ の成績から各計测点の変位方向を総体的に検討すること とする。

複模型の中切歯相当部の D’については，X軸方向す なわち左右方向に打いてほんど変化がみられずこれ は 3 種類の複模型とも同様であった。

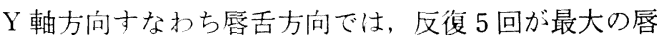
側変位率走して打り，反復回数が多くなるにつれ，D， はDに対して徐々に舌側の方向に変位する傾向がみられ た。これは， 3 種類の複模型とも同様であった。また， Z 軸方向子な子ち上下方向でも, 反復 5 回が最大変位を 示した.こ扎も3 種類め印象材々もに同様であった.

左分犬歯相当部 $C^{\prime}$ 扩よび $\mathrm{E}^{\prime}$ については，3種類の 複模型上も，唇舌方向であるX軸において反復 5 回が最 も大きく唇側に变位した。そして，さらに反復回数がふ える上舌侧に入る傾向寺した。

左右小臼歯相当部 $\mathrm{B}^{\prime}$ 扩よび $\mathrm{F}^{\prime}$ さらに左右大臼歯相 当部 $A^{\prime}$ 抢よび $G^{\prime} に つ い て も ， C^{\prime}$ 拉よび $E^{\prime}$ と同様な 傾向であった。

以上を考察する上X゙軸については， D’を除き各計測点 ともに，反復 5 回で唇（頪）側方向に，てして反復回数 がふえると舌側方向に変位しているが，これは複模型の 変位率の大小上水和膨張量の大小とが相似的であると考 えれば，反復回数が多くなるに徉ってその水和膨張量も 小さくなる(7)ことが考えられる。また，金型に対する印 象材の厚みが部位によって異なり，印象材が厚いほど印 象材内部温度が低下する と3) といらことから，乙れによっ て印象材の各部位によって泠却様相が異なり，それがひ ずみの相違となって現れたものと思わ机る。

また, D’については，左右方向の影響が他の部位（A'，

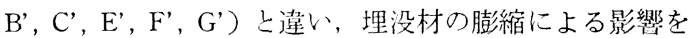
特に受け，他の部位上異なる変位在示したものと考えら れる。

また，埋没材自体からの影整をみると，これ自体が膨 張括よび収縮寸るという複雑な変位変形圭示す傾向があ る 12 14,20) とされている.したがって，印象材の反復使用 による印象材中の水分の割合の変化，すなわち水和膨張 の大小の差が埋没材の硬化時の寸法変化に大きく影響す るものと考えられる。

Y 軸に㧍いては，伊保内 ${ }^{17)}$ と同様であり，また鈴木 ${ }^{31)}$ の報告とも同様に，模型が後方に変位する傾向であっ t.
30 巻 4 号 (1986)

$Z$ 軸については, 先人の報告 ${ }^{17,20,31)}$ と同様に原型に対 して高さが増加した.これは，印象材の反復使用によっ て印象材中の液体成分が減少し, それによる印象材の弾 性ひずみの減少と, 複模型が硬化時に凹形に変位する20) ということに影響されているものと考える.

したがって，印象材の過度な繰返し使用が，鋳造床に おける適合性に大きな影響をおよぼすものと思われる.

本実験の結果より，石こう系埋没材用寒天複印象材の 反復使用は，リン酸塩系のそれ(7) と同様に，使用回数の 増加により弾性ひずみと明度および彩度が低下し，複模 型の精度にも影響をおよぼしたが，それの使用限度は， 複模型の変位率および各軸変位率から判断し, 反復 5 回 が限度であることが示唆された。

\section{第 5 章 結 論}

現在，補綴臨床に広く用いられている鋳造床の1つで ある $\mathrm{Ni}-\mathrm{Cr}$ 鋳造床の適合性を検討する目的で伊保内 ${ }^{17)}$ に準じ，寒天複印象材の反復使用が，弾性ひずみ，色彩 および複模型の精度におよぼす影響について検討した。 その結果, 以下の結論を得た。

1. 寒天複印象材の弾性ひずみは, その反復使用回数 が多くなるに従って, 漸次低下寸る傾向であった.

2. 寒天複印象材の色彩は，その反復使用回数が多く なるに従って，その明度拀よび彩度が低下する傾向であ った.

3. 複模型の三次元的変位率は, 反復使用 5 回目が最 大を示した.

4. 複模型の各軸変位率は, 中切歯相当部を除いて, 反復使用 5 回目が最大を示し, 外側に変位したが, 反復 回数が多くなると, 内側に変位する傾向であった.

5. 以上の結果から, 寒天複印象材は, その使用回数 が多くなると，複製される模型の変位率に影響を与え， 合金の鋳造収縮率㧍よび適合性から，その使用限度は 5 回までであることが示唆された。

稿老終わるにあたり，本研究に際して終始ご愁篤なるご指道 および校閲を睗った日本大学大木一三教授, またご尃攻の立場 からご指導を賜りました日本大学大橋正敬教授, 五十嵐孝義教 授, 森谷良彦教授に深甚なる感謝の意を表します，あわせて， 本実験にご助㝘とご援助をいただいた本学補緅学教室員各位お よび補緅学専攻大学院生各位に対し, 謝意を表します. 


\section{文献}

1）越中 優, 柳田千恵子, 引地弘子, 野口八九重 : 寒天印象 材をテストする, Dent. Echo, 36 : 16 27, 1976.

2）金竹哲也：歯科理工学通論，191 195，282 286, 永末書 店, 京都, 1978.

3）川原春幸, 権田悦通, 中村正明, 生内良男, 石崎順啓, 武 田昭二：歯科用コバルト・クロム合金䤻造法, 1 150, 医 歯薬出版, 東京, 1979.

4）長谷川二郎：歯科鋳造学, $26 \sim 101$, 医歯薬出版, 東京, 1980.

5） Craig, R.G. \& Peyton, F.A., 長谷川二郎訳 : 修復材料 の歯科理工学, 上巻, 第 5 版, $244 \sim 246$, クインテッセン ス出版, 東京, 1978.

6）野村順雄：鋳造床製作にあたっての理論的な考え方と実際 への応用(その 6 ), 歯科技工, $7: 39 \sim 49,1979$.

7）大木一三, 尾花甚一, 関根 弘, 平沼謙二, 松尾悦郎 : 床 用材料に関寸る問題点の検討, 補綴誌, $28: 1237 \sim 1252$, 1984.

8）蒜田 豊：リン酸系埋没材における水和膨張の抑制につい て, 歯科学報, $75: 1185 \sim 1197,1975$.

9）玉置敏夫, 杉上圭三, 斉藤俊司：リン醉塩采耐火模型の表 面処理について一第 1 報 処理後の耐火模型表面の観察所 見一，歯科枝工，5（3）: 77 82，1977.

10）福井寿男：鋳造用コバルト・クロム合金とリン酸塩采鋳型 材との界面反応物に関寸る研究, 管院大歯誌, 12 (1) : 31 $\sim 51,1974$.

11）安斉 碕, 菊地久二, 小川士朗, 岸川昭夫, 藤本一夫, 椎 原邦章: 埋没材の研究, 日大歯学: 695 698, 1973.

12）太田克子：複模型の精度について, 歯科技工, 3(4)：24〜 $28,1975$.

13）太田克子：リン酸塩系埋没材と水との微妙な関倸，D E， $22: 30 \sim 33,1972$.

14）太田克子：寒天印象材中におけるリン酸塩系埋没材の硬化 時膨張について, 愛院大㐘誌, $11: 231 \sim 243,1974$.

15）太田克子, 長谷川二郎, 林喜代治, 寺井貞寿：リン酸塩系 埋没材の水和膨張, 歯理工誌, $19: 53 \sim 54,1978$.

16）浮田恵司, 横井次郎 : 寒天印象による複模型の寸法変化に 及ぼす因子，歯科技工， $4: 53 \sim 60,1976$.

17）伊保内利一：リン酸塩系埋没材用寒天複印象材に関寸る研 究, 日大歯学, $60: 37 \sim 49,1986$.

18）野本 值，鈴木 暎：複製用寒天印象材について（第一 報), 歯材器誌, $6: 98 \sim 104,1951$.

19）野本 直, 鈴木 暎: 粉末寒天を利用した複製用印象材, 歯材器誌, $8: 48 \sim 54,1951$.

20）山田隆司：鋳造床の適合性に関寸る基礎的研究，補緅誌， $23: 288 \sim 309,1979$.
21）川原春幸：臨床家のための歯科材料学，医歯薬出版，110 $\sim 130,1946$.

22）野村順雄：鋳造床製作にあたっての理論的な考え方と実際 への応用（その 5 )，歯科技工， $7: 415 \sim 422 ， 1979$.

23) American Dental Association: Guide to Dental Materials and Devicec, 6th Edition, American Dental Association, Illinois, 227 232, 1972.

24) Ichiwata, T., Ueda, K., Takeda, T., Gotoh, H., Shirane, M., Nakamura, A., Ibonai, T., Morita, E., Satoh, Y. \& Ohki, K. : Research into the Colors of Denture Base Resin, J. Nihon Univ. Sch. Dent. $26: 30 \sim 38,1984$.

25）植田耕一郎, 武田友孝, 一和田寿樹, 小林 公, 中村隆之, 森田栄一, 後藤ひろみ, 宇美隆生, 佐藤吉則, 大來一三： 義菌床の着色に関吉る研究 [I ] 表面粗さおよび嗜好品が 及ぼす影䍩について, 補緅誌，29：85 93，1985.

26）岩尾 微：三次元测定機による中型間接法模型の膨縮精度 に関寸る研究，歯材器誌，34：136～147， 1977.

27）稻葉 繁，是沢恵三，萩原重一，鐘ヶ江修，川名孝義，绳 沢範之: 三次元座標测定機の歯学研究人の応用, 補緅誌, $25: 55 \sim 60,1981$.

28）土生博義, 平口久子，小林孝誌，田辺㨁紀，茂木孝之：三 次元座標測定システムの歯科材料研究人の志用, 日大歯 学, $56: 914 \sim 920$.

29）栈淑行, 石塚 享, 小泉政幸, 羽田京太郎, 富田 豊, 長島信也，松本幸士，崔 大均，庄司喜则，牟田茂，八 一庸行, 五十嵐孝義：診療姿势が支台歯形成面形態人及ぼ 寸影響について (第 1 報)，補緅誌，26：311～322， 1982.

30) 呈野 亨, 潤米芸仁, 久保时幸生, 泉田一藏, 田臭㨁孝, 山田博明, 山本克之, 祇園白信仁, 森谷良彦: 印象採得法 の基礎的検討（第 1 報），補緅綕，27：759 766，1983.

31）鈴木 章：画列模型の寸法䊑度に閣する基整的研究，歯 学, $71: 449 \sim 474,1983$.

32）大野紀和, 大場芳弘, 斎藤 一, 中島俊朗, 渡辺幸, 朴 政男, 日本人の崡, 歯列, 口監，咬台および頭顔部の形態 的研究, 愛院大画誌, $12: 57 \sim 63,1974$.

33）藤城鉄英：顎模型の寸法精度に関寸る研究，補緅誌，18： 382 402, 1975.

34）大村 平, 統㖕解析のはなし, 195 224, 日科技連出版, 東京, 1980 .

35）日本色彩学会：色彩科学ハンドブック，83 146，735 736, 東京大学出版会, 東京, 1982.

36）营原明喜：歯科用審美性修復材の硫化水素ガスによる変色 に関する研究, 龀材器誌, $2: 381 \sim 400,1982$.

37）有近徳幸：保存修復材 pile-A に関寸る测色的研栄，歯科 学報, 79 (7) : 1489 1516, 1979.

38）慶田安弘，他：コンポジットレジンの色洞に及ぼす袈装性

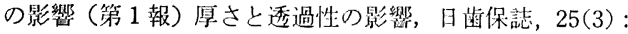


687 694, 1982.

39）福井敬和：各種コンポジットレジンの色調に関寸る研究, 日歯保誌, 24 (2) : 381 402, 1981.

40) Satoh, Y., Ichiwata, T., Tsukui, J., Ishigami, K., Kasai, S., Ueda, K., Takeda, T., Shirane, M., Gotoh, H., Ibonai, T., Nakamura, A., Morita, E. \& Ohki, K. : Questionnaire Survey of Metal Plate Construction, J. Nihon Univ. Sch. Dent., $25: 253 \sim$ $261,1983$.
41）大木一三：局部床義歯学実習要網，1 121, 歯界広報社, 東京, 1980 .

42）掘部 隆, 岡本佳三, 井上勇介, 松浦智二, 長岡幸一, 宫 口 嬚, 右近晋一：焼付用陶材の色彩分析について（第 1 報）陶材焼成時のノンプレシャス合金の色彩分析，福岡歯 大学会誌, $9: 695 \sim 701,1983$.

43）近藤豊一, 大沢 誠, 石岡 请: 寒天印象材に関する研究 （第 2 報）口腔内における寒天印象材に対する 泠却効果に ついて, 補緅誌, 19 (2) : 261 265, 1975. 